\title{
TWO NEW SPECIES OF CNEMASPIS STRAUCH, 1887 (SQUAMATA: GEKKONIDAE) FROM THE SERIBUAT ARCHIPELAGO, PAHANG AND JOHOR STATES, WEST MALAYSIA
}

\author{
INDRANEIL DaS ${ }^{1}$ AND L. LeE GRISMER ${ }^{2,3}$ \\ ${ }^{1}$ Institute of Biodiversity and Environmental Conservation, Universiti Malaysia Sarawak, 94300, \\ Kota Samarahan, Sarawak, Malaysia \\ ${ }^{2}$ Department of Biology, La Sierra University, 4700 Pierce Street, Riverside, CA 92512-8247, USA
}

\begin{abstract}
Two new species of Cnemaspis Strauch, 1887 are described from Pulau Tioman and Pulau Aur in the Seribuat Archipelago, Pahang and Johor States, respectively, off the southeast coast of West Malaysia. The Pulau Tioman species was previously allocated to C. nigridia by earlier workers, but is distinguishable from all other species on the basis of squamation, color pattern, and maximum size attained. The second new species from Pulau Aur is the first record of Cnemaspis from that island and is similarly distinguished from all other species on the basis of squamation and color pattern.
\end{abstract}

Key words: Cnemaspis baueri; Cnemaspis limi; Malaysia; New species; Pulau Aur; Pulau Tioman; Seribuat Archipelago; Systematics

Two species of the diurnal gekkonid genus Cnemaspis Strauch, 1887 were reported from Pulau Tioman $\left(02^{\circ} 43-54^{\prime} \mathrm{N}, 104^{\circ} 07-3.5^{\prime} \mathrm{E}\right)$ and Pulau Tulai $\left(02^{\circ} 43-54^{\prime} \mathrm{N}, 104^{\circ} 07-3.5^{\prime}\right.$ E), Pahang State, Seribuat Archipelago, peninsular Malaysia (Fig. 1) by Hendrickson (1966). The first, C. kendallii (Gray, 1845), is widespread, ranging throughout peninsular Malaysia, the Riau Archipelago, and Borneo (Das and Bauer, 1998). The systematic status of the second species has remained unclear, being referred to as Cnemaspis sp. (Hendrickson, 1966), C. nigridia (Smith, 1925) and, thereafter, the etymologically incorrect form C. nigridius by Denzer and Manthey (1991) and Manthey and Grossmann (1997). Cnemaspis nigridia is confined to the granite massif of Gunung Gading, the sandstone ranges of Gunung Pueh and Beremput, and the adjacent limestone-dominated Bau region of Sarawak, Borneo (Lim and Lim, 1999; Manthey and Grossmann, 1997). When comparing the Seribuat Archipelago populations to that from Borneo, Hendrickson (1966) and Dring (1979) noted subtle differences in squamation and the absence of preanal pores and enlarged femoral scales in males. We examined a series of specimens from Pulau Tioman and Pulau Aur and found them to be distinct from all other

\footnotetext{
${ }^{3}$ Correspondence: e-mail, lgrismer@LaSierra.edu
}

nominal species and from each other. Therefore, we describe them herein as new species.

\section{Materials AND Methods}

Specimens were collected by hand or with blowpipes. The holotypes and some of the paratypes were photographed prior to euthanization with pentobarbitol. All specimens were fixed in $10 \%$ buffered formalin and subsequently transferred to $70 \%$ ethanol within $30 \mathrm{~d}$ of collection. Scale counts and external observations of morphology were made using an Olympus SZX9 stereo dissecting microscope. Color notes on type specimens were taken from Fujichrome Velvia 50 ASA 35-mm slide transparency film and compared with color swatches of Smith $(1975,1981)$.

The following measurements were taken with Mitutoyo ${ }^{\mathrm{TM}}$ dial caliper (nearest 0.1 $\mathrm{mm}$ ): snout-vent length (SVL; from tip of snout to vent), tail length (TL; from vent to tip of unregenerated tail), tail width (TW; measured at base of tail), head length (HL; distance between posterior edge of last supralabial and snout tip), head width (HW; measured at angle of jaws), head depth (HD; maximum height of head, from occiput to throat), ear length (EL; greater ear length), forearm length (FA; distance between the palm and elbow), eye diameter (ED; greatest diameter of orbit), eye to nostril distance ( $\mathrm{E}-\mathrm{N}$; distance between anteriormost point of eyes and nostrils), eye to snout 